\title{
Psykisk helse i Helse- og levekårsundersøkelsen i 1998 I. Sosioøkonomiske forskjeller i psykisk helse og livsstil
}

\author{
Marit Rognerud, Bjørn Heine Strand og Odd Steffen Dalgard \\ Nasjonalt folkehelseinstitutt \\ Korrespondanse: Marit Rognerud, Nasjonalt folkehelseinstitutt, Postboks 4404 Nydalen, 0403 Oslo \\ E-post: marit.rognerud@fhi.no
}

\begin{abstract}
SAMMENDRAG
I denne undersøkelsen har vi valgt å studere betydningen av sosioøkonomisk status for psykisk helse (målt ved HSCL-25) samt fordelingen av livsstilsfaktorer, sosialt nettverk og sivil status som også kan virke inn på forekomsten av psykiske plager og lidelser i denne landsdekkende tverrsnittsundersøkelsen på et representativt utvalg på 9735 individer. Personlig inntekt og utdanningslengde er brukt som mål på sosioøkonomisk status.

Det er en signifikant sammenheng mellom sosioøkonomisk status og psykisk helse både for menn og kvinner - slik at hyppigheten av psykiske plager og lidelser avtar med økende sosioøkonomisk status. Det er imidlertid interessante forskjeller mellom de to kjønn, i det inntekt betyr mest for menn mens utdannelse betyr mest for kvinner. Betydningen av sosioøkonomisk status for den psykiske helse reduseres for begge kjønn når det kontrolleres for sivil status, sosial støtte og livsstil. Dette kan bl.a. tyde på at effekten av sosioøkonomisk status til en viss grad henger sammen med at høy status også bidrar til gode interpersonelle relasjoner og en livsstil som er positiv for den psykiske helse. Det finnes også en rekke andre mulige forklaringer på disse funnene (se diskusjon og konklusjon), men dette materialet er ikke egnet til å trekke konklusjoner om årsak og virkning.

Menn har generelt mindre symptomer på psykiske plager og lidelser enn kvinner ( 8,4 prosent av menn og 13,7 prosent av kvinner med HSCL-25 skåre over 1,75) til tross for at de har mindre sosial støtte enn kvinner. Menn har imidlertid bedre inntekt enn kvinner, men forskjellene i sosioøkonomisk status eller forskjellig nivå av noen av de andre målte variablene kan ikke forklare de store kjønnsforskjellene i forekomst av psykiske plager og lidelser i dette materialet.
\end{abstract}

\section{Rognerud M, Strand BH, Dalgard OS. Mental health in Norway 1998. II. Socioeconomic differences in mental health and lifestyle. Nor J Epidemiol 2002; 12 (3): 239-248.}

\section{ENGLISH SUMMARY}

This study is focusing on socioeconomic differences in psychological distress/mental health problems measured by Hopkins Symptom Check List 25 (HSCL-25) and some factors like lifestyle, social network and marital status of importance to mental health in this cross sectional survey covering a random sample of 9735 subjects. Levels of personal income and years of education are used as socioeconomic indicators.

There is a close link between socioeconomic status and mental health both for men and women, in such a way that the prevalence of psychological distress/mental health problems decreases with increasing socioeconomic status. There are, however, interesting gender differences in that income is most important for men while education is more important for women. The importance of socioeconomic status for mental health is lowered for both genders when we control for marital status, social support and lifestyle. This may among other things indicate that the effect of socioeconomic status to some degree is connected to the fact that high socioeconomic status is associated with good interpersonal relations and a lifestyle that is positive for mental health. There are also many other possible explanations for these findings (see discussion and conclusion), but this material is not suitable for making conclusions about causes and effects.

Men show fewer symptoms of psychological distress/mental health problems than women do $(8,4$ per cent of men and 13,7 per cent of women score above 1,75 on HSCL-25) despite less social support. Higher average income among men might be of some importance, but socioeconomic differences or differences in the levels of the other measured variables can not explain the gender differences in psychological distress/mental health problems found in this material.

\section{INNLEDNING}

Forskjeller i prevalens av psykiske plager og lidelser i ulike sosioøkonomiske grupper er godt dokumentert $\mathrm{i}$ internasjonal faglitteratur. Det er imidlertid ingen faglig enighet om forskjeller i levekår, alvorlige livshendelser, sosialt stress, sosial seleksjon eller andre faktorer er de viktigste årsakene til dette (1-6). I Helseog levekårsundersøkelsen i 1985 fant man ingen betydelige sosiale forskjeller i psykisk helse målt etter 
yrkesklasser i den norske befolkningen (7). Norsk epidemiologisk forskning om psykisk helse har i liten grad fokusert på systematiske forskjeller etter sosial klasse (8-20), selv om noen studier bekriver risikogrupper som er relatert til sosioøkonomiske forhold (8, 15,17). Vi har i dette materialet fra Helse- og levekårsundersøkelsen i 1998 valgt å studere sosioøkonomisk fordeling av psykisk helse samt fordelingen av noen andre faktorer som kan virke inn på forekomst av psykiske plager og lidelser.

Selvutfyllingsskjemaet av Hopkins Symptom Checklist med 25 spørsmål (HSCL-25) er brukt til å måle forekomst av psykiske plager og lidelser og en gjennomsnittlig skåre på over 1,75 er brukt som "cutoff" verdi (21). Vi har også sett på fordelingen av noen andre faktorer av betydning som sivil status, sosial støtte/fortrolige utenom nærmeste familie samt fysisk aktivitet og alkoholvaner og studert deres relasjon til hverandre og til symptomer på psykiske plager og lidelser. En rekke studier har vist at både sivil status og sosial støtte er faktorer nær knyttet til psykiske helseplager. Gifte/registrerte par har vanligvis færre psykiske plager og lidelser enn personer uten registrert partner. Sosial støtte fra f.eks. fortrolige venner/familiemedlemmer har vist seg som en sentral beskyttende faktor $i$ en rekke norske studier $(7,9,10,13,15,16,19$, 20). Fysisk aktivitet synes å fremme psykisk overskudd og velvære og brukes til dels som ledd $\mathrm{i}$ behandling av milde til moderate former for depresjon (22-28). Hvorvidt fysisk inaktivitet er en direkte risikofaktor for psykiske plager og lidelser er imidlertid noe usikkert. Betydningen av alkoholvaner og indikatoren "hyppighet av alkoholinntak" for psykisk helse er også omdiskutert (29-34). Vi har valgt å ta med alkoholvaner $\mathrm{i}$ denne studien både for å studere den sosioøkonomiske fordelingen i sammenheng mellom hyppighet av alkoholinntak og psykisk helse i en norsk populasjon samt interaksjonen mellom alkoholinntak og de øvrige nevnte faktorene. Hovedhensikten med å ta med alle disse faktorene er først å fremst å studere hvorvidt noen av de nevnte faktorene kan forklare noe av de sosiale ulikhetene i psykisk helse dersom man skulle finne det i dette materialet.

\section{Materiale OG Metode}

\section{Populasjon og utvalg}

Dataene for denne studien er hentet fra Statistisk sentralbyrås samordnede helse- og levekårsundersøkelse i 1998 (35). Dette er en landsdekkende tverrsnittsundersøkelse på et representativt utvalg av befolkningen. Undersøkelsen gjentas om lag hvert tredje år med spørsmål om bl.a. helse, levekår, arbeid og bomiljø. I 1998-undersøkelsen ble det i alt trukket 10000 personer over 15 år til å delta i spørreundersøkelsen. Det ble ikke trukket personer som var registrert som bosatt på institusjon. Utvalget besto av to deler, hovedutvalget og tilleggsutvalget. Hovedutvalget på 5000 personer ble trukket $\mathrm{i}$ to trinn etter Statistisk sentralbyrå sin standard utvalgsplan der hele landet er inndelt $i$ et sett utvalgsområder som igjen er gruppert i 109 strata. Disse ble primært intervjuet ved besøk ( 70,8 prosent). Telefonintervju ble tillatt dersom intervjuobjektet nektet å ta imot besøk eller hvis reisetiden var svært lang (29,2 prosent). Til tilleggsutvalget ble det trukket 5000 personer fra hele landet som ble intervjuet på telefon. Personer uten telefon ble kontaktet ved besøk hvis det var mulig. Intervjuet til tilleggsutvalget besto av et utvalg av spørsmålene fra intervjuet til hovedutvalget. Alle som ble trukket ut til enten hovedutvalget eller tilleggsutvalget, fikk tilsendt et postalt spørreskjema. På grunn av avgang fra utvalget etter intervju (døde, personer bosatt i utlandet eller på institusjon) fikk 9735 personer tilsendt et postalt skjema der bl.a. spørsmålene om psykiske plager og lidelser (HSCL25) og bruk av alkohol var inkludert.

Materialet er fordelt på kjønn og femårige aldersgrupper. Vi har valgt å begrense materialet til personer med alder 25 år og eldre i denne analysen fordi vi har brukt inntekt og utdanning som mål på sosial status og disse i større grad vil være ferdig med sin utdanning og kommet seg ut i arbeidslivet. Med et frafall på 28,1 prosent utgjorde materialet for denne analysen 6122 personer (2900 menn og 3222 kvinner). 2 prosent (118 personer) av disse ble ekskludert pga. mangelfull utfylling av HSCL-25. 15 prosent unnlot imidlertid å svare på spørsmålene om sosial støtte og fysisk aktivitet. For disse variablene har vi brukt det resterende materialet på 5229 individer som grunnlag for beregningene. Spørsmålet om inntak av alkohol var noe bedre utfylt og kun 7 prosent hadde unnlatt å svare på dette spørsmålet.

\section{Sosioøkonomiske mål}

Sosioøkonomisk status måles vanligvis etter yrkesklasse, utdanning og/eller inntekt. Vi har i denne analysen brukt inntekt og utdanning som mål på sosioøkonomisk status fordi dette er hierarkiske variabler som lett lar seg dele inn i passe store grupper og fordi opplysninger om inntekt og utdanning finnes for hele dette materialet. Statistisk sentralbyrå har utført registerkoplinger med bl.a. inntekt, formue, trygder, stønader, arbeidsforhold og utdanning. Inntektsdataene er hentet fra Likningsregisteret. Vi har brukt variabelen disponibel inntekt på individnivå. Det finnes ikke informasjon om husholdningsinntekt i dette datamaterialet. Disponibel inntekt er beregnet på bakgrunn av nettoinntekt til stat eller toppskattegrunnlag, pluss studielån, stipend og eventuelle trygdeytelser minus skatt. Disse er delt i 3 inntektsgrupper: Lav (25 prosent laveste inntekt), middels (50 prosent) og høy inntekt ( 25 prosent høyest inntekt).

Materialet ble også delt inn etter utdanningslengde i 3 grupper, henholdsvis lav, middels og høy utdanning. Dataene om utdanningslengde er hentet fra Utdanningsregisteret. Med lav utdanning regnes de som 
har inntil 9 års utdanning (t.o.m. ungdomsskole). Gruppen med middels utdanning har fullført videregående skole (nivå 1 og 2). Høy utdanning vil si fullført høyskole-, universitets- eller forskerutdannelse. Tabell 1 viser fordelingen av utdannings- og inntektsgruppene i dette materialet.

\section{Andre bakgrunns- og livsstilsvariabler}

\section{Sivil status}

Vi har her benyttet spørsmålet: Er du gift, samboende eller lever du for tiden ikke i noe fast parforhold? Det er her tre svaralternativer: 1. Gift/registrert partner. 2. Samboende. 3. Ikke i fast parforhold.

\section{Sosial støtte}

Som mål på sosial støtte har vi brukt spørsmålet: Bortsett fra medlemmer av din egen familie, har du noen som står deg nær, og som du kan snakke fortrolig med? Svaralternativene er enten ja eller nei. Som uttrykk for mangel på sosial støtte har vi i denne artikkelen brukt gruppen som her svarer nei; dvs. de som ikke har fortrolige utenom sin egen familie.

\section{Fysisk aktivitet}

Vi har her benyttet et spørsmål som lyder som følgende: Mosjonerer eller trener du av og til? I tilfelle hvor mange dager i uka mosjonerer eller trener du vanligvis? Svaralternativer: 1. Aldri. 2. Sjeldnere enn en gang i uka. 3. Mer enn en gang i uka. Vi har definert de som her svarer aldri som fysisk inaktive.

\section{Alkoholvaner}

Vi har benyttet spørsmålet i det postale selvutfyllingsskjemaet: Omtrent hvor ofte drakk du noen form for alkohol de siste 12 månedene? Regn også med de gangene du bare har drukket litt. Svaralternativene er: 1. 4-7 ganger i uken. 2. 2-3 ganger i uken. 3. Omtrent en gang i uken. 4. 2-3 ganger i måneden. 5. Omtrent en gang i måneden. 6. Sjeldnere enn en gang i måneden. 7. Sjeldnere enn en gang i året/aldri. I kategorien drikker ofte har vi regnet med kategori 1 og 2; dvs. de som drikker 2-3 ganger i uken eller oftere.

\section{Målemetode for psykiske plager og lidelser (avhengig variabel)}

Det er vanlig å skille mellom psykiske plager og psykiske lidelser. Mens de psykiske plagene kan være vanskelig å avgrense, lar de psykiske lidelsene seg dele inn etter diagnostiske systemer som f. eks ICD10, DSM-IV (36) mfl.

Det finnes en rekke godt utprøvete spørreskjemaer som omfatter et varierende antall symptomer på psykiske plager, først og fremst symptomer som er knyttet til angst og depresjon. Slike spørreundersøkelser er basert på at den som undersøkes angir om ulike symptomer er til stede, og i tilfelle i hvor stor grad. Hvis mengden og styrken på symptomene overstiger en bestemt skåre, snakker en om et "psykiatrisk case" uten angivelse av noen bestemt diagnose. For nærmere diagnostisering må det foretas et klinisk intervju i tillegg. Det viser seg vanligvis at 50-60 prosent av slike "psykiatriske cases" som blir identifisert ved høy skåre på spørreskjema får en eller flere psykiatriske diagnoser ved et klinisk intervju (37-42). Når det gjelder forholdet mellom spørreskjemametoder og psykiatrisk diagnostikk, kan det for øvrig henvises til artikkelen av Inger Sandanger et al i dette temanummeret av Norsk Epidemiologi.

Som spørreskjema har en i denne undersøkelsen brukt Hopkins Symptom Checklist med 25 spørsmål (HSCL-25), som måler "distress" i form av angst, depresjon og somatisering. Instrumentet er brukt i en rekke av de andre undersøkelsene som omtales i dette temanummeret, og er også er mye brukt i andre norske undersøkelser $(41,42)$. Som indikator på at det foreligger et "psykiatrisk case" har en brukt en cut-off verdi på 1,75. Personer som unnlot å svare på fem eller flere av spørsmålene i HSCL-25 ble utelatt fra analysene. Dette utgjorde 2 prosent (118 personer). Der det ikke var forkastning ble de blanke erstattet med gjennomsnittsverdien for utvalget for hvert enkelt spørsmål.

\section{Statistiske metoder}

Alle analysene ble stratifisert på kjønn, og bare de over 24 år ble med i analysene. Aldersjusterte rater ble beregnet med direkte standardisering, og Norges 1981 befolkning i 5 års aldersgrupper ble brukt som standardbefolkning. Pearsons korrelasjon ble beregnet mellom alle variablene. Det ble benyttet logistisk regresjon og både univariate og multiple regresjonsmodeller ble beregnet. Regresjonsmodellene ble bygget opp ved å legge til en og en variabel. For hver modell ble det beregnet devians for å avgjøre hvor godt modellen passet til dataene. Statistikkpakken SPSS 10.1 ble benyttet til de statistiske analysene.

\section{ReSUlTATER}

Lav inntekt (25 prosent lavest inntekt) utgjorde totalt 13 prosent av mennene og 35 prosent av kvinnene i materialet. De med middels inntekt utgjorde henholdsvis 49 prosent av mennene og 51 prosent av kvinnene. Høyeste inntektskvartil (25 prosent høyest inntekt) utgjorde 38 prosent av mennene og 14 prosent av kvinnene i materialet. De med lav utdanning, dvs. 9 år eller mindre utdanning (t.o.m. ungdomsskole), utgjorde totalt 18 prosent av mennene og 23 prosent av kvinnene $i$ materialet. Gruppen med middels utdanning har fullført videregående skole (nivå 1 og 2). Disse utgjorde til sammen 55 prosent av mennene og 50 prosent av kvinnene i materialet. De med høy utdanning (høyskole-, universitets- og forskerutdannelse) utgjorde 27 prosent av både mennene og kvinnene i materialet.

Tabell 1 viser fordeling etter alder og kjønn og tabell 2 etter utdanningslengde og inntektsnivå for hvert kjønn separat, justert for alder. 
Tabell 1. Fordeling etter alder og kjønn.

\begin{tabular}{lrrr|rrr}
\hline & \multicolumn{3}{c|}{ Menn } & \multicolumn{3}{c}{ Kvinner } \\
\cline { 2 - 7 } Aldersgruppe & $25-44$ & $45-64$ & $65+$ & $25-44$ & $45-64$ & $65+$ \\
Antall & 1273 & 1032 & 595 & 1443 & 1056 & 723 \\
\hline Utdanning (prosent) & & & & & & \\
$\quad$ Lav: $<9$ år (t.o.m. ungdomsskole) & 8 & 21 & 35 & 7 & 25 & 53 \\
$\quad$ Middels: 10-12 år (videregående skole) & 62 & 50 & 47 & 56 & 50 & 39 \\
$\quad$ Høy: Universitet/høyskole/forsker & 29 & 29 & 17 & 38 & 24 & 8 \\
Inntekt (prosent) & 14 & 6 & 24 & 24 & 28 & 69 \\
$\quad$ Lav: 0-25\% laveste & 48 & 43 & 61 & 57 & 59 & 28 \\
$\quad$ Middels: 26-75\% & 38 & 51 & 15 & 19 & 14 & 4 \\
$\quad$ Høy: 76-100\% Høyeste & 23 & 15 & 21 & 21 & 22 & 54 \\
Sivilstand ${ }^{1}$ (Prosent uten parforhold) & 16 & 21 & 34 & 4 & 10 & 23 \\
Sosial støtte ${ }^{1}$ (Prosent uten noen fortrolige) & 24 & 28 & 37 & 21 & 26 & 42 \\
Fysisk aktivitet ${ }^{2}$ (Prosent som aldri mosjonerer) & 18 & 23 & 18 & 6 & 12 & 6 \\
Alkoholvaner (Prosent som drikker ofte) & 8 & 9 & 10 & 11 & 15 & 16 \\
HSCL>1,75 (prosent) & \multicolumn{3}{c}{} & & &
\end{tabular}

Tabell 2. Alderjusterte rater for menn og kvinner 25 år og eldre etter utdannings- og inntektsnivå.

\begin{tabular}{|c|c|c|c|c|c|c|c|c|c|c|c|c|}
\hline & \multicolumn{6}{|c|}{ Menn } & \multicolumn{6}{|c|}{ Kvinner } \\
\hline & \multicolumn{3}{|c|}{ Utdanning } & \multicolumn{3}{|c|}{ Inntekt } & \multicolumn{3}{|c|}{ Utdanning } & \multicolumn{3}{|c|}{ Inntekt } \\
\hline & Lav & middels & høy & Lav & middels & høy & Lav & middels & høy & Lav & middels & høy \\
\hline \multicolumn{13}{|l|}{ Sivilstand } \\
\hline Prosent uten parforhold & 21 & 21 & 19 & $40^{*}$ & $23 *$ & $15^{*}$ & 28 & 28 & 30 & $19 *$ & $34 *$ & $53 *$ \\
\hline Antall i hver gruppe (nevner) & 411 & 1342 & 679 & 301 & 1175 & 993 & 593 & 1428 & 390 & 929 & 1428 & 390 \\
\hline \multicolumn{13}{|l|}{ Sosial støtte } \\
\hline Prosent uten fortrolige & 24 & 23 & 18 & 24 & 24 & 18 & 13 & 11 & 5 , & $15^{*}$ & $8 *$ & $5 *$ \\
\hline Antall i hver gruppe (nevner) & 407 & 1337 & 677 & 300 & 1172 & 986 & 591 & 1352 & 758 & 927 & 1424 & 390 \\
\hline \multicolumn{13}{|l|}{ Fysisk aktivitet } \\
\hline Prosent aldri mosjonerer & $38^{*}$ & $30 *$ & $18^{*}$ & $34 *$ & $29 *$ & $25^{*}$ & $36^{*}$ & $27 *$ & $16^{*}$ & $38 *$ & $30 *$ & $18 *$ \\
\hline Antall i hver gruppe (nevner) & 592 & 1354 & 758 & 409 & 1342 & 679 & 409 & 1342 & 679 & 301 & 1174 & 992 \\
\hline \multicolumn{13}{|l|}{ Alkoholvaner } \\
\hline Prosent som drikker ofte & 10 & 14 & $27^{\prime}$ & 18 & $12^{\prime}$ & 25 & 5 & 7 & $16^{\prime}$ & 6 & 8 & $15^{\prime}$ \\
\hline Antall i hver gruppe (nevner) & 503 & 1537 & 753 & 371 & 1384 & 1087 & 675 & 1537 & 836 & 1054 & 1614 & 430 \\
\hline \multicolumn{13}{|l|}{ HSCL $>1,75$} \\
\hline \multirow{2}{*}{$\begin{array}{l}\text { Prosent Prosent } \\
\text { Antall i hver gruppe (nevner) }\end{array}$} & $12^{\prime}$ & 9 & 6 ' & $17^{*}$ & $10 *$ & $6^{*}$ & $20 *$ & $13^{*}$ & $9 *$ & $16^{\prime}$ & 13 & $10^{\prime}$ \\
\hline & 503 & 1547 & 754 & 375 & 1392 & 1088 & 685 & 1554 & 839 & 1085 & 1615 & 432 \\
\hline
\end{tabular}

* Forskjellene mellom hvert av tallene er statistisk signifikante på mindre enn 5 prosent nivå $(\mathrm{p}<0,05)$.

'Enten er forskjellen mellom dette tallet og de øvrige 2 tallene i ruten eller mellom dette tallet og det andre tallet merket med' statistisk signifikant på mindre enn 5 prosent nivå $(\mathrm{p}<0,05)$.

Utdanningslengde varierer sterkt med alder. Gruppen med lav utdanning utgjør 8 prosent av menn og 7 prosent av kvinner mellom 25-44 år. I aldersgruppen over 65 år hadde 35 prosent av mennene og 53 av kvinnene lav utdanning. Andelen med høy utdanning er høyere blant kvinner (38 prosent) enn blant menn (29 prosent) i aldersgruppen 25-44 år, mens det i den eldste aldersgruppen er flere menn (17 prosent) enn kvinner ( 8 prosent) med høy utdanning. Inntekt fordeler seg noe annerledes enn utdanning etter kjønn og alder. Generelt er det langt flere kvinner enn menn med lav inntekt. For kvinner over 65 år er det bare 4 prosent som har høy inntekt.

$\AA$ være uten fast parforhold er langt vanligere for eldre kvinner enn for eldre menn (tabell 1). Hele 54 prosent av kvinnene over 65 år hadde ikke fast partner. $\AA ̊$ være uten fast parforhold ser ikke ut til å ha sammenheng med utdanningsnivå verken for menn eller kvinner (tabell 2).

Forholdet mellom sivil status og inntekt, derimot, viser et interessant mønster. Blant menn med lav inntekt er det en større andel uten fast parforhold enn blant menn med høy inntekt. For kvinner er det motsatt, i gruppen med høy inntekt er det flest uten fast parforhold.

Mangel på fortrolige/sosial støtte utenom familien synes imidlertid å være langt mer utbredt blant menn enn blant kvinner $\mathrm{i}$ alle aldersgrupper $(\mathrm{p}<0,05)$. For begge kjønn er det en aldersgradient (tabell 1). For menn finner vi ingen signifikante forskjeller i sosial 
støtte som kan relateres til inntekt eller utdanning. Blant kvinner ser det derimot ut som de høyere sosiale lag har mer sosial støtte (tabell 2).

Andelen fysisk inaktive er tilnærmet like stor og øker noe med alderen for begge kjønn (tabell 1). Det er flere fysisk inaktive $\mathrm{i}$ de lavere sosioøkonomiske lag av befolkningen. Forskjellene i fysisk aktivitet er imidlertid klart større etter utdanning enn etter inntekt særlig for menn (tabell 2).

Å drikke alkohol oftere enn 2-3 ganger pr. uke er langt vanligere for menn enn for kvinner. Aldersgruppen mellom 45-64 år har størst tendens til å "drikke ofte". For kvinnene er disse aldersforskjellene signifikante på 5 prosent nivå (tabell 1). Det er imidlertid klart størst andel som drikker mer enn 2-3 ganger pr. uke i gruppen med høyest utdanning/inntekt for begge kjønn $(\mathrm{p}<0,05$, tabell 2$)$.

Tabell 1 viser at andelen som skårer over 1,75 på HSCL-25 varierer relativt lite med alder, selv om det er en tendens til høyere andel med stigende alder. Derimot er det betydelig høyere andeler $\mathrm{i}$ alle aldersgrupper blant kvinner enn blant menn $(\mathrm{p}<0,01)$. Tabell 2 viser at det er en klar sosial gradient med høyere forekomst av psykiske plager og lidelser i de lavere sosioøkonomiske lag for begge kjønn. Den sosiale gradienten er imidlertid størst etter inntekt for menn, mens inndeling etter utdanningsnivå gir størst forskjeller hos kvinner. Forskjellene $\mathrm{i}$ andel menn med HSCL$25>1,75$ er signifikante på fem prosentnivå mellom hver av inntektsgruppene, mens kun høyeste og laveste gruppe er signifikant forskjellige etter utdanning. Tabell 2 viser at hele 20 prosent av kvinnene med lav utdanning skårer over 1,75 på HSCL-25. Korrelasjonen mellom inntekt og utdanning er for menn 0,21 $(p<0,01)$ og for kvinner $0,35(p<0,01)$; dvs. at det er en noe sterkere sammenheng mellom utdanningsnivå og inntekt hos kvinner enn hos menn.

Korrelasjonene mellom de uavhengige variablene og mellom disse og HSCL-25>1,75 for hvert kjønn er vist $\mathrm{i}$ tabell 3. De uavhengige variablene som mangel på sosial støtte (ingen fortrolige), sivilstand (uten fast parforhold) og fysisk inaktivitet er positivt korrelert til HSCL-25>1,75. Dvs. at dette er faktorer som er assosiert med en høyere forekomst av psykiske plager og lidelser. Hyppigere alkoholinntak, høyere utdanning og høyere inntekt derimot er signifikant negativt korrelert til HSCL-25>1,75; dvs. at høyere nivå av disse faktorene er assosiert med lavere forekomst av psykiske plager og lidelser.

Mangel på sosial støtte (ingen fortrolige) har ikke sammenheng med sivilstand; dvs. at sosial støtte utenfor familien ikke er avhengig av om man er gift/har registrert partner, er samboende eller uten fast parforhold. Imidlertid er det en signifikant sammenheng mellom det å være fysisk inaktiv, drikke sjelden og mangle sosial støtte. Alle disse faktorene har også sterk sammenheng med utdanning og inntektsnivå (høyere forekomst i lavere sosioøkonomiske lag). Kvinner uten fast parforhold har høyere forekomst av fysisk inaktivitet og sjelden alkoholinntak. Kvinner uten fast parforhold har oftere lavere utdanning, men høyere inntekt, enn kvinner i parforhold. For menn er forholdet omvendt når det gjelder inntekt. Menn uten fast parforhold tenderer heller til å ha lavere inntekt enn menn som er gift eller samboende. Vi ser av tabell 3 at kvinner uten fast parforhold også tenderer til å være mer fysisk aktive og drikke mer alkohol enn kvinner i parforhold. Dette er ikke tilfelle for menn.

Tabell 3 viser også at de som drikker alkohol oftere har større sannsynlighet for å ha mer sosial støtte, være mer fysisk aktive, ha høyere utdanning og inntekt og jevnt over bedre psykisk helse enn de som drikker mer sjelden.

For å se nærmere på effekten av de enkelte variable når det kontrolleres for effekten av de andre, har vi foretatt en trinnvis multippel regresjonsanalyse. I det følgende vil vi gi en summarisk beskrivelse av resultatene for hvert enkelt trinn, mens resultatet når samtlige variable tas inn i analysen fremgår av tabell 4 .

\section{Menn}

Når en tar inn variablene alder, inntekt og utdanning $\mathrm{i}$ regresjonsmodellen for menn, er det bare inntekt som slår ut som en faktor med signifikant betydning for forekomst av HSCL $>1,75(\mathrm{p}<0,01)$. OR for gruppen med lav inntekt er 1,72 sammenliknet med de med middels inntekt. Tar vi inn "Sivil status" i modellen ser vi at dette også er en faktor av vesentlig betydning $(\mathrm{OR}=2,04$ for gruppen uten fast parforhold sammenliknet med de som er gift/har registrert partner; $\mathrm{p}<0,01$ ).

Tabell 3. Innbyrdes korrelasjon mellom variablene - menn (kvinner i parentes). Pearsons tosidig korrelasjonskoeffisient.

\begin{tabular}{lccccc}
\hline & $\begin{array}{c}\text { Sosial støtte } \\
\text { (mangler) }\end{array}$ & $\begin{array}{c}\text { Sivilstatus } \\
\text { (ikke parforhold) }\end{array}$ & $\begin{array}{c}\text { Fysisk aktivitet } \\
\text { (inaktivitet) }\end{array}$ & $\begin{array}{c}\text { Alkoholvaner } \\
\text { (oftere) }\end{array}$ & $\begin{array}{c}\text { HSCL-score } \\
\text { (høyere) }\end{array}$ \\
\hline Sosial støtte (mangler) & 1 & $-0,01(0,014)$ & $0,123^{* *}\left(0,113^{* *}\right)$ & $-0,046^{*}\left(-0,124^{* *}\right)$ & $0,084^{* *}\left(0,123^{* *}\right)$ \\
Sivil status (uten parforh.) & 1 & $-0,04\left(-0,064^{* *}\right)$ & $-0,01\left(-0,046^{*}\right)$ & $0,13^{* *}\left(0,082^{* *}\right)$ \\
Fysisk aktivitet (inaktiv) & & 1 & $-0,075^{* *}\left(-0,121^{* *}\right)$ & $0,05^{*}\left(0,119^{* *}\right)$ \\
Alkoholvaner (oftere) & & & & 1 & $-0,072^{* *}\left(-0,079^{* *}\right)$ \\
Utdanning (høyere) & $-0,08^{* *}\left(-0,19^{* *}\right)$ & $-0,04\left(-0,10^{* *}\right)$ & $-0,15^{* *}\left(-0,18^{* *}\right)$ & $0,24^{* *}\left(0,23^{* *}\right)$ & $-0,09^{* *}\left(-0,13^{* *}\right)$ \\
Inntekt (høyere) & $-0,08^{* *}\left(-0,18^{* *}\right)$ & $-0,23^{* *}\left(0,06^{* *}\right)$ & $-0,07^{* *}\left(-0,13^{* *}\right)$ & $0,20^{* *}\left(0,20^{* *}\right)$ & $-0,14^{* *}\left(-0,079^{* *}\right)$ \\
\hline
\end{tabular}


Tabell 4. Enkeltfaktorenes betydning for HSCL25>1,75 når alle faktorene er justert for i en multippel regresjonsmodell (trinnvis analyse er beskrevet i resultatkapittelet).

\begin{tabular}{|c|c|c|c|c|c|c|c|}
\hline & \multicolumn{3}{|c|}{ Menn } & \multicolumn{3}{|c|}{ Kvinner } \\
\hline & & Antall & OR & $(95 \% \mathrm{KI})$ & Antall & OR & $(95 \% \mathrm{KI}))$ \\
\hline Alder & & & 1,00 & $(0,98-1,00)$ & & 0,99 & $(0,99-1,01)$ \\
\hline \multirow[t]{3}{*}{ Inntekt } & Lav & 564 & 1,39 & $(0,84-1,52)$ & 599 & 1,13 & $(0,96-2,01)$ \\
\hline & Middels & 1203 & 1,00 & Referanse & 1298 & 1,00 & Referanse \\
\hline & Нøу & 606 & 0,85 & $(0,66-1,24)$ & 673 & 0,90 & $(0,54-1,34)$ \\
\hline \multirow[t]{3}{*}{ Utdanning } & Lav & 382 & 1,20 & $(0,80-1,81)$ & 516 & $1,52 * *$ & $(1,10-2,08)$ \\
\hline & Middels & 1315 & 1,00 & Referanse & 1305 & 1,00 & Referanse \\
\hline & Нøу & 676 & 0,73 & $(0,48-1,11)$ & 749 & $0,65^{* *}$ & $(0,47-0,90)$ \\
\hline \multirow[t]{3}{*}{ Sivilstand } & Gift/reg. partner & 1540 & 1,00 & Referanse & 1531 & 1,00 & Referanse \\
\hline & Samboende & 367 & 0,98 & $(0,84-1,82)$ & 327 & 1,24 & $(0,84-1,82)$ \\
\hline & Uten parforhold & 466 & $2,05 * *$ & $(1,37-2,36)$ & 712 & 1,80 ** & $(1,41-2,97)$ \\
\hline \multirow[t]{2}{*}{ Sosial støtte } & Fortrolige - Ja & 1880 & 1,00 & Referanse & 2325 & 1,00 & Referanse \\
\hline & Fortrolige - Nei & 493 & $1,71 * *$ & $(1,20-2,42)$ & 245 & $2,95 * *$ & $(2,11-4,13)$ \\
\hline \multirow[t]{3}{*}{ Fysisk aktivitet } & $>1$ gang pr. uke & 1346 & 1,00 & Referanse & 1541 & 1,00 & Referanse \\
\hline & $<1$ gang pr. uke & 376 & 1,04 & $(0,66-1,66)$ & 368 & 0,87 & $(0,59-1,28)$ \\
\hline & Aldri & 649 & 1,11 & $(0,78-1,59)$ & 661 & $1,34^{*}$ & $(1,02-1,75)$ \\
\hline \multirow[t]{7}{*}{ Alkoholvaner } & $<1$ gang pr. år/aldri & 239 & $2,41 * *$ & $(1,38-4,20)$ & 468 & 0,95 & $(0,63-1,43)$ \\
\hline & < 1 gang pr. mnd. & 405 & 1,66 & $(1,00-2,77)$ & 660 & 0,95 & $(0,65-1,37)$ \\
\hline & ca. 1 gang pr. mnd. & 309 & 1,44 & $(0,82-2,55)$ & 322 & 0,85 & $(0,54-1,33)$ \\
\hline & 2-3 ganger pr. mnd. & 470 & 0,95 & $(0,54-1,67)$ & 475 & 0,70 & $(0,45-1,07)$ \\
\hline & ca. 1 gang pr. uke & 554 & 1,00 & Referanse & 450 & 1,00 & Referanse \\
\hline & 2-3 ganger pr. uke & 320 & 1,27 & $(0,69-2,31)$ & 149 & 1,07 & $(0,60-1,92)$ \\
\hline & 4-7 ganger pr. uke & 76 & $2,70 * *$ & $(1,23-5,92)$ & 46 & 1,24 & $(0,51-2,99)$ \\
\hline
\end{tabular}

** signifikant på 1 prosent nivå eller mindre

* signifikant på 5 prosent nivå eller mindre

Denne faktoren reduserer imidlertid betydningen av inntekt noe, men inntekt er fortsatt signifikant på mindre enn 5 prosentnivå etter at vi har tatt sivil status inn i modellen. Tar vi inn sosial støtte finner vi at denne faktoren også er av vesentlig betydning for forekomst av HSCL-25>1,75 selv etter at man har justert for faktorer som alder, inntekt, utdanning og sivil status. Gruppen uten noen fortrolige har 1,73 ganger høyere risiko for HSCL-25>1,75 sammenliknet med gruppen som har fortrolige $(p<0,01)$. Hyppighet av alkoholkonsum viser seg også å slå ut i modellen $(p<0,01)$. Sammenliknet med den største gruppen som drikker en gang i uken, har gruppen menn som drikker 4-7 ganger pr. uke 2,71 ganger økt risiko $(\mathrm{p}<0,05)$. Denne gruppen utgjør imidlertid bare 3 prosent av antall menn $\mathrm{i}$ materialet. De som drikker sjeldnere enn en gang $i$ året $(\mathrm{OR}=2,43)$ eller sjeldnere enn en gang pr. måned $(\mathrm{OR}=1,67)$ har også betydelige høyere risiko for HSCL-25>1,75 sammenliknet med de som drikker en gang pr. uke. Når vi tar inn alkohol i regresjonsmodellen, faller betydningen av inntekt ut. Fysisk aktivitet gir ingen signifikant bedre modelltilpasning og dermed ingen selvstendig tilleggseffekt. Tabell 4 viser effekten av de enkelte variable når alle er tatt inn i modellen.

Blant menn er det bare manglende parforhold, mangel på fortrolige venner og et svært lavt eller svært sjelden (mindre enn 1 gang $\mathrm{i}$ året eller aldri) eller svært hyppig (4-7 ganger i uka) inntak av alkohol, som har en signifikant sammenheng med mye psykiske plager og lidelser når man har kontrollert for de andre variablene i modellen.

\section{Kvinner}

Når en tar inn variablene alder, inntekt og utdanning $\mathrm{i}$ regresjonsmodellen for kvinner er det bare utdanning som slår ut som en signifikant faktor for forekomst av HSCL-25>1,75. OR for kvinner med lav utdanning er 1,6 og de med høy utdanning 0,63 sammenliknet med gruppen med middels utdanning (den største gruppen satt lik 1). Justert for utdanning og inntekt er sivilstatus også en vesentlig faktor for omfanget av de målte psykiske problemene hos kvinner. OR for de uten registrert partner for å ha HSCL-25>1,75 er 1,68 sammenliknet med de som er gift/har registrert partner. Sivil status reduserer ikke betydningen av lavere utdanning som risikofaktor. Tar vi inn sosial støtte/fortrolige utenom nærmeste familie i modellen, er utdanningsnivå og sivil status fortsatt av tilnærmet like stor betydning. Sosial støtte/fortrolige viser seg å være en faktor av stor selvstendig betydning. OR for HSCL-25>1,75 for gruppen uten noen fortrolige utenom nærmeste familie er hele 2,85 sammenliknet med de som har fortrolige utenom nærmeste familie. Alkoholforbruk viser seg ikke å ha betydning for forekomst av HSCL-25>1,75 blant kvinner når vi har justert for de andre faktorene $\mathrm{i}$ modellen. Fysisk aktivitet, derimot, viser seg å gi en 
signifikant bedre modelltilpasning for kvinner. Gruppen som aldri mosjonerer har økt risiko for HSCL25>1,75 (OR på 1,34 sammenliknet med gruppen som mosjonerer mer en en gang $\mathrm{i} u k a ; p<0,05)$ selv når man har justert for alle de andre variablene i modellen. Som det fremgår av tabell 4 , har følgende variable en negativ effekt på den psykiske helse hos kvinner når man kontrollerer for effekten av samtlige variable $\mathrm{i}$ modellen: Lav utdanning, manglende parforhold, mangel på fortrolige venner og fysisk inaktivitet.

\section{Betydningen av kjonn}

Odds ratio for kvinner i forhold til menn for HSCL$25>1,75$ er $1,72(95 \%$ KI 1,42-2,07). Utfører vi en trinnvis regresjonsanalyse for begge kjønn samlet finner vi at betydningen av kjønn reduseres noe når det tas hensyn til at menn har høyere inntekt enn kvinner (OR reduseres fra 1,72 til 1,42). Når det imidlertid også tas hensyn til at menn har færre fortrolige enn kvinner, øker igjen betydningen av kjønn, slik at OR for kvinner i den samlede modell blir 1,67. Menn har altså mindre symptomer på psykiske plager og lidelser enn kvinner til tross for at de har mindre sosial støtte enn kvinner, men muligens noe på grunn av at de har bedre inntekt.

\section{DISKUSJON}

I denne undersøkelsen skårer totalt 8,4 prosent av menn og 13,7 prosent av kvinner over en terskelverdi på 1,75 på HSCL-25. Tilsvarende tall fra Helse- og levekårsundersøkelsen i 1985 og 1995 ga betydelig lavere prevalens (7). I 1985 var dataene samlet inn ved personlig intervju og dette er ikke korrekt metode for HSCL-25 som er ment å være et selvutfyllingsskjema. I 1995-undersøkelsen er det brukt samme metode som i denne undersøkelsen. Helseundersøkelsen i 1995 ga en tilsvarende prevalens på 3,7 prosent for menn og 6,9 prosent for kvinner (43). Den store økningen i prevalens fra 1995 til 1998 kan ikke gjenspeile noen tilsvarende økning i forekomst av angst og depresjon $\mathrm{i}$ befolkningen i løpet av en så kort periode, og er antakelig knyttet til ulikheter i bruk av metode i de to undersøkelser (det er foreløpig uklart hva disse ulikheter består i). Moum hevder at det er lite trolig at det var noen reell økning av angst og depresjon i befolkningen i perioden 1985 til 1995 - data fra spørsmål om nervøse symptomer i levekårsundersøkelsene peker i den retning (44).

Under alle omstendigheter er det sannsynlig at undersøkelsene viser noe lavere tall enn de reelle, fordi de med psykiske plager nok er mindre tilbøyelige til å delta i slike befolkningsundersøkelser enn andre. Hansen og medarbeidere fant således i en undersøkelse i Troms at forekomsten av psykiske plager og lidelser var 2,5 ganger høyere blant de som ikke møtte til helseundersøkelse sammenliknet med de som møtte både for kvinner og menn (14). Selv om man i den foreliggende undersøkelse har reist på hjemmebesøk til
70,8 prosent for å utføre intervjuene (telefonintervju til de øvrige) og delt ut spørreskjemaene personlig, og frafallet er relativt lavt (28,1 prosent) til å være en helseundersøkelse, må man anta at det også her kan være en overrepresentasjon av personer med psykiske plager og lidelser blant ikke-deltakerne.

I data fra en tverrsnittsundersøkelse er det problematisk å trekke slutninger om årsak og virkning. Dette gjelder ikke minst ved den type data som inngår i denne undersøkelsen, der det kan være vanskelig å si om de psykososiale problemer, for eksempel mangel på venner, er en årsak til de psykiske helseproblemer eller snarere en konsekvens. Det er også godt mulig at en assosiasjon mellom to eller flere variable skyldes en felles bakenforliggende faktor. Det samme gjelder for forholdet mellom sosioøkonomiske faktorer som inntekt eller utdanning og psykiske plager og lidelser. Vi kan ikke si noe om hva som er årsak eller virkning. Det er for eksempel mulig at assosiasjonen mellom lite sosial støtte og psykiske helseproblemer kan forklares gjennom personlighet, som disponerer både for lite kontakt med andre og øket risiko for psykiske plager. I den utstrekning de foreliggende resultater skal kunne tolkes i retning av kausale sammenhenger, må en da i betydelig grad trekke på resultatene fra andre, longitudinelle undersøkelser. I Helseundersøkelsen i 1985 fant man små sosioøkonomiske forskjeller når man benyttet yrkesgrupper som mål på sosioøkonomisk status. Om det er noen reell økning i sosioøkonomiske forskjeller i psykisk helse over tid er vanskelig å si når man ikke har brukt de samme sosioøkonomiske målene. At frafallet i 1985-undersøkelsen var noe mindre enn i vårt materiale (21,3 prosent), er trolig ikke avgjørende i denne sammenheng (42) selv om frafallsundersøkelser kan tyde på at det først og fremst er de sosialt mest vanskeligstilte, yngre voksne og de med størst psykiske problemer som faller fra $(45,14)$.

Sivil status samt det å ha fortrolige (sosial støtte) utenom den nærmeste familie er faktorer som er nær knyttet til lavere forekomst av psykiske plager og lidelser, både for kvinner og menn, uavhengig av sivil og sosioøkonomisk status i dette materialet. Dette er i samsvar med funn i en rekke andre undersøkelser i Norge, også longitudinelle, og passer med at sosial støtte har en positiv effekt på den psykiske helse (7,9$13,15,16,18)$, kanskje spesielt i tilknytning til negative livshendelser. Sosioøkonomiske forskjeller i prevalens av HSCL-25>1,75 er størst inndelt etter inntekt for menn og etter utdanning for kvinner. Imidlertid ser mye av inntektsforskjellene i psykisk helse hos menn ut til å kunne tilskrives at menn som tjener mer, oftere er gift/har registrert partner og "drikker ofte". At sivil status gift/registrert parforhold er knyttet til lavere forekomst av psykiske plager og lidelser er lite kontroversielt $(7,19)$, men at hyppigere inntak av alkohol $\mathrm{i}$ seg selv skal være en positiv faktor for den psykiske helse er overraskende, og fortoner seg som tvilsomt. Hyppigere inntak av alkohol er både for menn og kvinner assosiert med høy inntekt og lav forekomst av 
psykiske plager (tabell 3) i dette materialet. Av tabell 4 fremgår det imidlertid at både de menn som drikker svært lite (sjeldnere enn 1 gang pr. måned eller aldri) og de som drikker mest (4-7 ganger pr. uke eller mer) har en signifikant økt risiko for psykiske plager. Vårt datamateriale sier imidlertid ikke noe om hvor mye man drikker pr. gang. Gmel og medarbeidere hevder at hyppighet av alkoholinntak er en dårlig indikator på alkoholproblemer (33). Mest trolig har hyppighet av alkoholinntak i de mengder som er vanlig i Norge i seg selv liten betydning for forekomsten av psykiske plager, men at hyppig alkoholinntak er vanligere $\mathrm{i}$ høyere sosioøkonomiske lag av befolkningen der nivået av positive faktorer som mestring, selvfølelse, sosialt nettverk etc. er høyt og risikofaktorer som f.eks. negative livshendelser kanskje er lavt. At det ikke er noen enkel sammenheng mellom alkoholforbruk og forekomst av psykiske plager og lidelser, passer for øvrig med funn fra en kanadisk oppfølgingsstudie som bl.a. finner at det ikke er noen sammenheng mellom inntak av alkohol og utvikling av depresjon i den generelle befolkningen (ikke en gang grupper som drakk mer en drink pr. dag hadde øket hyppighet av psykiske plager i denne studien), mens grupper med ekstreme drikkemønstre (karakteristisk for alkoholikere) oftere rapporterte om depresjon (31). I en amerikansk oppfølgingsstudie på 6 år fant man at man måtte opp i doser på 2 eller flere drinker daglig for at alkoholinntak var assosiert med økt forekomst av depresjon og andre psykiske lidelser (34). Hyppighet av alkoholinntak slår ikke ut som noen faktor av selvstendig betydning for psykiske plager og lidelser hos kvinner i dette materialet. Kvinner drikker også i snitt betydelig mindre enn menn.

Når vi gjør en trinnvis regresjonsanalyse for kvinner med variablene alder, utdanning og inntekt, er det bare utdanning som slår ut som en faktor av betydning for forekomsten av psykiske plager og lidelser - og ikke inntekt som hos menn. Det er mulig at personlig inntekt er et dårligere mål på økonomisk evne blant kvinner fordi det i større grad enn for menn beror på ektefelles inntekt. Kanskje ville resultatene vært annerledes dersom vi opererte med husholdningsinntekt som mål på økonomisk evne, men det finnes ikke data om husholdningsinntekt koblet til dette datamaterialet. Tabell 4 viser at effekten av utdannelse hos kvinner ikke kan forklares av forskjeller i livsstil, sosial støtte eller sivil status. Forskjellene som vi ser hos kvinner relatert til utdanningsnivå, blir bare ubetydelig redusert ved å ta inn sosial støtte og mosjonsvaner i regresjonsmodellen, selv om disse faktorene er av signifikant betydning for den psykiske helse og høyt korrelert med utdanningsnivå. Når høy inntekt hos kvinner, i motsetning til hos menn, ikke har noen selvstendig betydning for den psykiske helse, henger dette antakelig sammen med at høy inntekt hos kvinnene i dette materialet er assosiert med manglende parforhold. Enslige kvinner vil ha større behov for egeninntekt enn kvinner i parforhold, og også ha større anledning til fulltidsjobb enn kvinner som har en betydelig arbeidsbyrde i hjemmet, spesielt i fasen med små barn. Dette betyr at den positive helseeffekt av høy inntekt hos kvinnen enten motvirkes ved å være enslig, eller ved å være dobbeltarbeidende. Under forutsetning av at det skjer en endring i det tradisjonelle kjønnsrollemønster, med større likhet mellom de to kjønn når det gjelder fordeling av arbeid, både i og utenfor hjemmet, skulle en da forvente at forskjellene mellom de to kjønn avtar når det gjelder relasjonen mellom psykisk helse og egeninntekt.

Foruten sivil status og fortrolige venner (sosial støtte) utenom nærmeste familie, trer også fysisk aktivitet fram som en faktor av betydning for prevalens av psykiske plager og lidelser hos kvinner. Som tidligere nevnt, er det imidlertid vanskelig å trekke slutninger om årsak og virkning basert på data fra en tverrsnittsundersøkelse, som her. Selv om vi finner en sammenheng mellom fysisk aktivitet og få psykiske plager, kan grunnen til dette like gjerne være at det er individer som har god helse og få psykiske plager som har det nødvendige overskuddet til å drive regelmessig mosjonsaktivitet. Moum rapporterer f.eks. om en sterk sammenheng mellom fysisk sykdom og psykiske plager og lidelser i 1985-materialet; især blant kvinner (7).

Det forhold at kvinner har en større hyppighet av psykiske plager enn menn i det foreliggende materialet, selv når det kontrolleres for forskjeller i inntekt og livsstil, er interessant. Dette er i samsvar med det Weich og medarbeidere fant (46), nemlig at forskjellene i psykiske plager og lidelser ikke kunne forklares ved forskjeller i sosiale roller. En mulighet som da står tilbake er at de symptom-mål på psykisk helse som oftest brukes (f.eks. HSCL-25) i større grad oppfanger internaliserende symptomer som er mest typisk for kvinner (f.eks. angst og depresjon), mens eksternaliserende symptomer som er mer vanlige blant menn (f.eks. utagerende og antisosial atferd) i mindre grad oppfanges ved de anvendte målemetoder. Det kan imidlertid også være en tendens til å "sykeliggjøre" emosjonelle reaksjoner som er mer vanlige hos kvinner enn hos menn (47).

\section{KONKLUSJON}

Både hos menn og kvinner er det en sammenheng mellom sosioøkonomisk status og psykisk helse, slik at hyppigheten av psykiske plager og lidelser avtar med økende sosioøkonomisk status i dette representative utvalget av den norske befolkningen. Det er imidlertid interessante forskjeller mellom de to kjønn, i det inntekt betyr mest hos menn mens utdannelse betyr mest hos kvinner.

At betydningen av sosioøkonomisk status for den psykiske helse reduseres for begge kjønn når det kontrolleres for sosial støtte og sunn livsstil, kan tyde på at effekten av sosioøkonomisk status til en viss grad henger sammen med at høy status bidrar til gode interpersonelle relasjoner og sunn livsstil, som i seg selv er positivt for psykisk helse. På den andre siden er det 
også rimelig å anta at disse forhold, ikke minst et godt sosialt nettverk, kan bidra til økonomisk framgang og god psykisk helse. Det kan også hende at forholdet er omvendt; at det snarere er psykiske plager og lidelser som disponerer for lav inntekt/utdanning, manglende sosialt nettverk, enslig status og mindre sunne leve- vaner. Til sist foreligger også den mulighet at en felles bakenforliggende faktor, for eksempel personlighet og personlige ressurser, forklarer både det gode nettverk, den høye sosioøkonomiske status og den gode psykiske helse. Alt dette representerer utfordringer til videre forskning.

\section{REFERANSER}

1. Dohrenwend BP. Sosioeconomic status (SES) and psychiatric disorders. Are the issues still compelling? Soc Psychiatry Psychiatr Epidemiol 1990; 25: 41-7.

2. Dohrenwend BP, Levav I, Shrout PE, et al. Sosioeconomic status and psychiatric disorders: the causationselection issue. Science 1992; 255: 946-52.

3. Stansfield S. Social support and social cohesion. In: Marmot M, Wilkinson R, eds. Social Determinates of Health. Oxford: Oxford University Press, 1999.

4. Stansfeld SA, Head J, Marmot MG. Explaining social class differences in depression and well-being. Soc Psychiatry Psychiatr Epidemiol 1998; 33: 1-9.

5. Eaton WW, Muntaner C, Bovaso G, Smith C. Socioeconomic status and depressive syndrome: the role of inter- and intra-generational mobility, government assistance, and work environment. J Health Soc Behav 2001; 42 (3): 277-94.

6. Regier DA, et al. One-month prevalence of mental disorders in the United States and sociodemographic characteristics: the Epidemiological Catchment Area study. Acta Psychiatr Scand 1993; 88: 35-47.

7. Moum T, Falkum E, Tambs K, Vaglum P. Sosiale bakgrunnsfaktorer og psykisk helse. I: Moum T, red. Helse i Norge. Sykdom, livsstil og bruk av helsetjenester. Oslo: Gyldendal, 1991: 47-62.

8. Claussen B. Deprived of work and health. Reseach report 1. Oslo: Folkehelsa, 1994.

9. Dalgard OS, Bjørk S, Tambs K. Social support, negative life events and mental health - a longitudinal study. Br J Psychiatry 1995; 166: 29-35.

10. Dalgard OS, Døhlie E, Ystgaard M. Sosialt nettverk, helse og samfunn. Oslo: Universitetsforlaget, 1995.

11. Dalgard OS. Bomiljø og psykisk helse. Oslo: Universitetsforlaget, 1980.

12. Dalgard OS, Sørensen T, Sandanger I, Brevik JI. Psychiatric interventions for prevention of mental health disorders. A psychosocial perspective. Int J Technol Assess Health Care 1996; 12: 604-17.

13. Dalgard OS. Social integration and mental health promotion. Int J Ment Health Promot 1999; 1: 32-6.

14. Hansen V, Jacobsen BK, Arnesen E. Prevalence of serious psychiatric morbidity in attenders and nonattenders to a health survey of a general population: the Tromsø Health Study. Am J Epidemiol 2001; 154 (10): $891-4$.

15. Mathiesen KS, Tambs K, Dalgard OS. The influence of social class, life strains, and social support on mental distress symptoms in mothers of toddlers. Soc Psychiatry Psychiatr Epidemiol 1999; 34: 61-72.

16. Ystgaard M. Life stress, social support and psychological distress in late adolescence. Soc Psychiatry Psychiatr Epidemiol 1997; 32: 277-83.

17. Nærde A, Tambs K, Mathiesen KS, Dalgard OS, Samuelsen SO. Symptoms of anxiety and depression among mothers of pre-school children: effect of chronic strain related to children and child care-taking. $J$ Affect Disord 2000; 58: 181-99.

18. Olstad R, Sexton H, Søgaard AJ. The Finnmark Study: Social support, social network and mental distress in a prospective population study. Soc Psychiatry Psychiatr Epidemiol 1999; 34: 519-25.

19. Sosial- og helsedepartementet. Faktarapport om årsaker til psykiske plager og lidelser. Oslo: Sosial- og helsedepartementet, 2000.

20. Norges forskningsråd. Rådet for psykisk helse. Ny viten om psykisk helse - utbredelse og forebyggende tiltak. Rapport fra formidlingskonferansen 23.03.2000. Oslo: Norges forskningsråd, 2000.

21. Derogatis LR, Lipman RS, Rickels K, Uhlenhuth EH, Covi L. The Hopkins Symptom Checklist (HSCL): a self-report symptom inventory. Behav Sci 1974; 19 (1): 1-15.

22. Martinsen EW. Fysisk aktivitet for sinnets helse. Tidsskr Nor Laegeforen 2000; 120: 3054-6.

23. Ommundsen Y. Kan idrett og fysisk aktivitet fremme psykososial helse blant barn og ungdom? Tidsskr Nor Logeforen 2000; 120: 3573-7.

24. Martinsen EW, Medhus A, Sandvik L. Effects of aerobic exercise on depression: a controlled study. $B M J$ 1985; 291: 109

25. Martinsen EW, Strand J, Paulsson G, Kaggestad J. Physical fitness level in patients with anxiety and depressive disorders. Int J Sports Med 1989; 10: 58-62. 
26. Sexton H, Søgaard AJ, Olstad R.. How are mood and exercise related? Results from the Finnmark study. Soc Psychiatry Psychiatr Epidemiol 2001; 36: 348-53.

27. Camacho TC, Roberts RE, Lazarus NB, Kaplan GA, Cohen RD. Physical activity and depression: evidence from the Alameda County Study. Am J Epidemiol 1991; 134: 220-31.

28. Farmer ME, Locker BZ, Moscicki EK, Dannenberg AL, Larson DB, Radloff LS. Physical acivity and depression symptoms: the NHANESI epidemiological follow-up study. Am J Epidemiol 1998; 128: 1340-51.

29. Torikka A, Kaltiala-Heino R, Rimpela A, Rantanan P. Depression, drinking and substance use among 14- to 16-year-old Finnish adolescents. Nord J Psychiatry 2001; 55 (5): 351-7.

30. Tambs K, Harris JR, Magnus P. Genetic and environmental contributions to the correlation between alcohol consumption and anxiety and depression. Results from a bivariate analysis of Norwegian twin data. Behav Genet 1997; 27: 241-50.

31. Wang J, Patten SB. Alcohol consumption and major depression: findings from a follow-up study. Can $J$ Psychiatry 2001; 46 (7): 632-8.

32. Perreira KM, Sloan FA. Excess alcohol consumption and health outcomes: a 6 year follow-up of men over age of 50 from the health and retirement study. Addiction 2002; 97 (3): 301-10.

33. Gmel G, Heeb JL, Rehm J. Is frequency of drinking an indicator of problem drinking? A psychometric analysis of a modified version of the alcohol use disorders identification test in Switzerland. Drug Alcohol Depend 2001; 64 (2): 151-63.

34. Green CA, Pope CR. Depressive symptoms, health promotion, and health risk behaviors. Am J Health Promot 2000; 15 (1): 29-34.

35. Roll-Hansen D. Samordnet levekårsundersøkelse 1998 - tverrsnittsundersøkelsen. Dokumentasjonsrapport Nr. 40. Oslo: Statistisk sentralbyrå, 1999.

36. American Psychiatric Association. Diagnostic and Statistical Manual of Mental Disorders - Fourth Edition (DSM-IV), Washington DC: American Psychiatric Association, 2000.

37. Sullivan M, Karlsson J. The Swedish SF-36 Health Survey III. Evaluation of criterion-based validity: Results from normative nopulation. J Clin Epidemiol 1998; 51 (11): 1105-13.

38. Derogatis LR, Richels K, Rock AF. The SCL-90-R and the MMPI: A step in the validation of a new selfreport scale. Br J Psychiatry 1976; 128: 280-9.

39. Glass RM, Allan AT, Uhlenhut EH, et al. Psychiatric screening in a medical clinic. Arch Gen Psychiatry 1978; 35: 1189-95.

40. Nettelbladt P, Hansson L, Stefansson CG, Borgquist L, Nordstrom G. Test characteristics of the Hopkins Symptom Check List-25 (HSCL-25) in Sweden, using the Present State Examination (PSE-9) as a caseness criterion. Soc Psychiatry Psychiatr Epidemiol 1993; 28 (3): 130-3.

41. Sandanger I, Moum T, Ingebrigtsen G, Dalgard OS, Sørensen T, Bruusgaard D. Concordance between symptom screening and diagnostic procedure: the Hopkins Symptom Checklist-25 and the Composite International Diagnostic Interview I. Soc Psychiatry Psychiatr Epidemiol 1998; 33: 345-54.

42. Lavik NJ, Laake P, Hauff E, Solberg Ø. The use of self-reports in psychiatric studies of traumatized refugees: Validation and analysis of HSCL-25. Nord J Psychiatry 1999; 1: 53-8.

43. Norgeshelsa (http://www.folkehelsa.no/fag/nhis/last2.html).

44. Moum T. Selvrapportering av psykiske plager ved intervju og skjema for selvutfylling. I: Ekeberg $\varnothing$, Finseth A, Friss S, Opjordsmoen S, red. Pasient og behandler: Personlighet, atferd og samspill i klinisk virksomhet. Oslo: Universitet i Oslo, 1998.

45. Statistisk sentralbyrå. Helseundersøkelsen 1985. ISBN 82-537-2494-2. Oslo: Statistisk sentralbyrå, 1987.

46. Weich S, Sloggett A, Lewis G. Social roles and the gender differences in rates of common mental disorders in Britain: a 7-year, population-based cohort study. Psychol Med 2001; 31 (6): 1055-64.

47. Sandanger I. Occurrence of psychiatric disorders - an epidemiological study, conceptual, methodological, and empirical issues. Oslo: Institute of general practice and community medicine and Institute group of psychiatry, University of Oslo, 1999. 